\title{
Extrapulmonary manifestations of chronic obstructive pulmonary disease in a mouse model of chronic cigarette smoke exposure.
}

Citation for published version (APA):

Gosker, H. R., Langen, R. C., Bracke, K. R., Joos, G. F., Brusselle, G. G., Steele, C., Ward, K. A., Wouters, E. F., \& Schols, A. M. (2009). Extrapulmonary manifestations of chronic obstructive pulmonary disease in a mouse model of chronic cigarette smoke exposure. American Journal of Respiratory Cell and Molecular Biology, 40(6), 710-716. https://doi.org/10.1165/rcmb.2008-0312OC

Document status and date:

Published: 01/01/2009

DOI:

10.1165/rcmb.2008-03120C

Document Version:

Publisher's PDF, also known as Version of record

\section{Document license:}

Taverne

Please check the document version of this publication:

- A submitted manuscript is the version of the article upon submission and before peer-review. There can be important differences between the submitted version and the official published version of record.

People interested in the research are advised to contact the author for the final version of the publication, or visit the DOI to the publisher's website.

- The final author version and the galley proof are versions of the publication after peer review.

- The final published version features the final layout of the paper including the volume, issue and page numbers.

Link to publication

\footnotetext{
General rights rights.

- You may freely distribute the URL identifying the publication in the public portal. please follow below link for the End User Agreement:

www.umlib.nl/taverne-license

Take down policy

If you believe that this document breaches copyright please contact us at:

repository@maastrichtuniversity.nl

providing details and we will investigate your claim.
}

Copyright and moral rights for the publications made accessible in the public portal are retained by the authors and/or other copyright owners and it is a condition of accessing publications that users recognise and abide by the legal requirements associated with these

- Users may download and print one copy of any publication from the public portal for the purpose of private study or research.

- You may not further distribute the material or use it for any profit-making activity or commercial gain

If the publication is distributed under the terms of Article $25 \mathrm{fa}$ of the Dutch Copyright Act, indicated by the "Taverne" license above, 


\title{
Extrapulmonary Manifestations of Chronic Obstructive Pulmonary Disease in a Mouse Model of Chronic Cigarette Smoke Exposure
}

\author{
Harry R. Gosker¹, Ramon C. J. Langen ${ }^{1}$, Ken R. Bracke², Guy F. Joos², Guy G. Brusselle ${ }^{2}$, Chad Steele ${ }^{3}$, \\ Kimberly A. Ward ${ }^{1}$, Emiel F. M. Wouters ${ }^{1}$, and Annemie M. W. J. Schols ${ }^{1}$ \\ ${ }^{1}$ Department of Respiratory Medicine, Nutrition and Toxicology Research Institute Maastricht, Maastricht University, Maastricht, The Netherlands; \\ ${ }^{2}$ Department of Respiratory Medicine, Ghent University Hospital, Ghent, Belgium; and ${ }^{3}$ Department of Medicine, Division of Pulmonary, Allergy, \\ and Critical Care Medicine, University of Alabama at Birmingham School of Medicine, Birmingham, Alabama
}

\begin{abstract}
Cigarette smoking is the most commonly encountered risk factor for chronic obstructive pulmonary disease (COPD), reflected by irreversible airflow limitation, frequently associated with airspace enlargement and pulmonary inflammation. In addition, COPD has systemic consequences, including systemic inflammation, muscle wasting, and loss of muscle oxidative phenotype. However, the role of smoking in the development of these extrapulmonary manifestations remains rather unexplored. Mice were exposed to cigarette smoke or control air for 6 months. Subsequently, emphysema was assessed by morphometry of lung tissue, and blood cytokine and chemokine levels were determined by a multiplex assay. Soleus, plantaris, gastrocnemius, and tibialis muscles were dissected and weighed. Muscle fiber typing was performed based on I, IIA, IIB, and IIX myosin heavy-chain isoform composition. Lungs of the smokeexposed animals showed pulmonary inflammation and emphysema. Moreover, circulating levels of primarily proinflammatory proteins, especially TNF- $\alpha$, were elevated after smoke exposure. Despite an attenuated body weight gain, only the soleus showed a tendency toward lower muscle weight after smoke exposure. Oxidative fiber type IIA proportion was significantly reduced in the soleus. Muscle oxidative enzyme activity was slightly reduced after smoke exposure, being most prominent for citrate synthase in the soleus and tibialis. In this mouse model, chronic cigarette smoke exposure resulted in systemic features that closely resemble the early signs of the extrapulmonary manifestations observed in patients with COPD.
\end{abstract}

Keywords: cigarette smoking; systemic inflammation; skeletal muscles; murine model; chronic obstructive pulmonary disease

Chronic obstructive pulmonary disease (COPD) is a disease characterized by irreversible airflow limitation frequently associated with airspace enlargement and pulmonary inflammation (1). Cigarette smoking has devastating adverse effects on lung health, and is therefore by far the most commonly encountered risk factor for COPD (2). In addition, evidence is growing that smoking has adverse extrapulmonary effects as well, including systemic inflammation (3) and peripheral muscle dysfunction, with underlying muscular abnormalities (4). However, the extent to which cigarette smoking per se contributes to systemic inflammation and muscular impairment in COPD remains unclear.

(Received in original form August 11, 2008 and in final form October 24, 2008) This work was supported by Concerted Research Action, Ghent University, Belgium. H.R.G. is a recipient of an award from The Netherlands Asthma Foundation (project no. 3.2.05.038) and R.C.J.L. is a recipient of a Veni grant from the Netherlands Organization of Scientific Research. K.R.B. is a postdoctoral researcher of the Fund for Scientific Research in Flanders.

Correspondence and requests for reprints should be addressed to Harry R. Gosker, Ph.D., Department of Respiratory Medicine, Maastricht University, NUTRIM, P.O. Box 616, 6,200 MD Maastricht, The Netherlands. E-mail: H.Gosker@ pul.unimaas.nl

Am J Respir Cell Mol Biol Vol 40. pp 710-716, 2009

Originally Published in Press as DOI: 10.1165/rcmb.2008-03120C on November 6, 2008

Internet address: www.atsjournals.org

\section{CLINICAL RELEVANCE}

Cigarette smoke not only leads to pulmonary impairments, but also results in extrapulmonary manifestations frequently observed in chronic obstructive pulmonary disease (COPD). This mouse model is a valuable tool for the further examination of the role of smoking in the systemic pathogenesis in COPD.

Systemic inflammation in patients with COPD manifests itself as enhanced activation of circulating inflammatory cells and increased levels of proinflammatory cytokines and acute-phase proteins, such as TNF- $\alpha$ and C-reactive protein (CRP) (5). Muscle impairment in COPD comprises loss of muscle strength and/or endurance associated with loss of muscle quantity and quality, respectively. A major cause of reduced muscle quantity is muscle fiber atrophy $(6,7)$, of which we have shown that especially the fast-twitch type-IIX fibers are affected (6). The loss of muscle quality is primarily reflected by loss of oxidative phenotype: a slow-to-fast or I-to-II fiber-type shift is a consistent finding in lower-limb muscles of patients with COPD $(7,8)$, in which fiber type transitions seem to play an important role (9). In addition, activities of key enzymes of oxidative metabolism, such as citrate synthase (CtS) and 3-hydroxyacyl-CoA dehydrogenase (HAD), were found to be reduced in these patients, whereas activities of glycolytic enzymes, such as phosphofructokinase (PFK), appeared to be increased $(10,11)$. Interestingly, features of systemic inflammation, muscle atrophy, and loss of muscle oxidative phenotype have been associated with smoking populations $(3,12)$. It is thus feasible that cigarette smoke per se is involved in the development of these extrapulmonary manifestations.

The aim of this study was therefore to determine in an animal model whether chronic cigarette smoke exposure has systemic consequences similar to those observed in COPD. For this an established chronic-smoking mouse model was used (13). After 6 months of cigarette smoke exposure, these mice exhibit an emphysematous phenotype, including pulmonary inflammation and airspace enlargement. We attempted to evaluate the systemic consequences of cigarette smoke exposure in a detailed manner, including a panel of circulating cytokines and chemokines, body and muscle mass, and muscle fiber type distribution and metabolic profile.

\section{MATERIALS AND METHODS}

\section{Experimental Design}

A total of 26 male C57Bl/6 mice (7 to 9 wk old) were purchased from Harlan (Zeist, The Netherlands). The local ethics committee (Ghent, Belgium) approved all in vivo manipulations. Exposure to cigarette 
smoke or air was performed using a smoking apparatus (D. Kobayashi, Washington University Medical Center, St. Louis, MO) with the chamber adapted for a group of mice (chamber volume of 4.7 liters). An optimal smoke/air ratio of 1:6 was obtained (14). Mice $(n=13)$ were exposed to the smoke of five cigarettes (reference cigarette $2 \mathrm{R} 4 \mathrm{~F}$ without filter; University of Kentucky, Lexington, KY), four times a day, with 30-minute smoke-free intervals, 5 days per week for 24 weeks in total (15). The control group $(n=13)$ was exposed to air. Body weights of 8 animals in each group were determined immediately before and after these 24 weeks.

\section{Collection of Tissues}

After the 24 weeks, mice were killed by an intraperitoneal injection with an overdose of pentobarbital. Blood for cytokine and chemokine profile was collected by cardiac puncture. For bronchoalveolar lavage (BAL), three washes with $300 \mu$ l Hank's balanced salt solution (HBSS; free of ionized calcium and magnesium but supplemented with $0.05 \mathrm{mM}$ sodium EDTA) followed by three washes with $1 \mathrm{ml}$ HBSS were performed via a tracheal cannula, and the six fractions were recovered by gentle manual aspiration. Lung tissue was obtained as described previously (15): the left lung was fixed with a $4 \%$ paraformaldehyde infusion through the tracheal cannula, excised, and fixed for another 4 hours, after which it was embedded in paraffin for morphometric analyses. The soleus, gastrocnemius, tibialis anterior, and plantaris muscles were collected from both hind limbs using standardized dissection methods. The muscles were weighed using a microbalance and frozen in liquid nitrogen for further analysis. Finally, tibia length was determined using a caliper.

\section{BAL}

The six lavage fractions were pooled, centrifuged, and the cell pellet was washed twice and finally resuspended in $1 \mathrm{ml} \mathrm{HBSS}$. A total cell count was performed in a Bürcker chamber (Novolab, Geraardsbergen, Belgium), and the differential cell counts (on at least 400 cells) were performed on cytocentrifuged preparations using standard morphologic criteria after May-Grünwald-Giemsa staining (15).

\section{Morphometry of the Lungs}

Quantification of airspace enlargement was performed in 16 mice $(n=$ 8 in each group), as described previously (15). In short, $3-\mu \mathrm{m}$ sections were cut from the paraffin-embedded lung tissue and stained with hematoxylin and eosin. For each animal, 10 fields, together representative of all parts of the lung, were captured at $\times 200$ magnification in a blinded fashion. Two independent observers measured the mean linear intercept $(\mathrm{Lm})$ by means of a $100-\times 100-\mu \mathrm{m}$ grid passing randomly through the lung, with $\mathrm{Lm}$ being calculated as the total length of the grid lines divided by the number of alveolar intercepts.

\section{Blood Cytokine and Chemokine Profile}

Serum cytokine and chemokine protein levels were quantified in 16 mice ( $n=8$ in each group) using a Mouse Cytokine 23-Plex Panel (Bio-Rad, Hercules, CA), which is based on Luminex technology and simultaneously measures IL- $1 \alpha,-1 \beta,-2,-3,-4,-5,-6,-9,-10,-12(\mathrm{p} 40)$, -12 (p70), -13, -17, TNF- $\alpha$, RANTES (regulated on activation, normal $\mathrm{T}$-cell expressed and secreted), macrophage inflammatory proteins $1 \alpha$ and $1 \beta, \mathrm{MCP} 1, \mathrm{KC}$, granulocyte and granulocyte-macrophage colonystimulating factor, IFN- $\gamma$, and eotaxin protein. Briefly, anti-cytokine/ chemokine antibody-conjugated beads were added to individual wells of a 96-well filter plate and adhered using vacuum filtration. After washing, $50 \mu \mathrm{l}$ of prediluted standards (range 1.95-32,000 pg/ml) or serum were added, and the filter plate shaken at $300 \mathrm{rpm}$ for 30 minutes at room temperature. Thereafter, the filter plate was washed, and $25 \mu \mathrm{l}$ of prediluted multiplex biotin-conjugated detection antibody was added for 30 minutes. After washing, $50 \mu$ l of prediluted streptavidin-conjugated PE was added for 10 minutes, followed by an additional wash and the addition of $125 \mu \mathrm{l}$ of Bio-Plex assay buffer to each well. The filter plate was analyzed using the Bio-Plex Protein Array System, and concentrations of each cytokine and chemokine were determined using Bio-Plex Manager version 3.0 software (Bio-Rad).

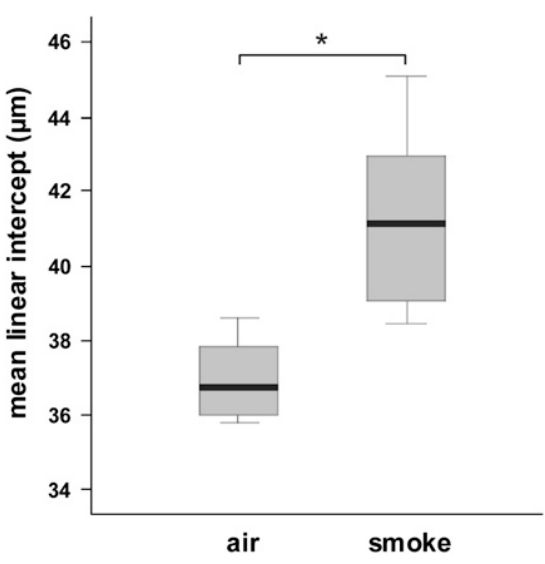

Figure 1. Box plot showing the mean linear intercept as an index of emphysema in mice exposed to air or cigarette smoke for 6 months. Black bars represent medians. ${ }^{*} P \leqslant 0.001$.

\section{Muscle Analyses}

A $5 \%(\mathrm{wt} / \mathrm{vol})$ homogenate of the muscles of all 26 mice was prepared by dispersion (Polytron PT 1,600 E; Kinematica AG, Luzern, Switzerland), followed by 1-minute sonication (Branson 2210; Branson Ultrasonics Corporation, Danbury, CT) of the muscle tissue in SET buffer $(250$ $\mathrm{mM}$ sucrose, $2 \mathrm{mM}$ EDTA, $10 \mathrm{mM}$ TRIS, $\mathrm{pH}$ 7.4). Samples were centrifuged $\left(10 \mathrm{~min}, 10,000 \times g, 4^{\circ} \mathrm{C}\right)$, and the supernatant was used for enzyme activity assays: PFK (EC 2.7.11) (16), HAD (EC 1.1.1.35) (17), CtS (EC 2.3.3.1) (18), cytochrome $c$ oxidase (EC 1.9.3.1) (19), and glycogen phosphorylase (EC 2.4.1.1) (20) were analyzed spectrophotometrically (Multiskan Spectrum; Thermo Labsystems, Breda, The Netherlands). The remaining pellet was resuspended in three volumes of ice-cold extraction buffer $\left(100 \mathrm{mM} \mathrm{Na}_{4} \mathrm{O}_{7} \mathrm{P}_{2}, 10 \mathrm{H}_{2} \mathrm{O}, 5 \mathrm{mM}\right.$ EDTA, $1 \mathrm{mM}$ DTT, $\mathrm{pH} 8.5)$, incubated on ice for 30 minutes, and centrifuged $\left(10 \mathrm{~min}, 10,000 \times \mathrm{g}, 4^{\circ} \mathrm{C}\right)$. From this, the supernatant was used for myosin heavy-chain (MyHC) isoform analysis, as described by Talmadge and Roy (21). Gels were run for 22 hours using a Protean II xi Cell gel electrophoresis system (Bio-Rad, Veenendaal, The Netherlands) at $20 \mathrm{~mA}$ with increasing voltage to a maximum of $350 \mathrm{~V}$. About $1.0 \mu \mathrm{g}$ of protein was loaded per lane. Gels were silver stained (Silver Stain Plus Kit; Bio-Rad), scanned, and photographed with a scanning densitometer (Fluor-S MultiImager; Bio-Rad), after which bands were quantified using Quantity One software (Bio-Rad). MyHC isoforms I, IIA, IIB, and IIX were expressed proportionally to each other.

\section{Statistical Analysis}

Data were analyzed using SPSS version 13.0 for Windows (SPSS Inc., Chicago, IL). Data were analyzed with the unpaired Student's $t$ test (corrected for unequal variances, if appropriate) or the Pearson correlation test. In case of smaller group sizes $(n=8)$, data were analyzed with the Mann-Whitney U test and the Spearman correlation test. Testing the presence or absence of MyHC IIB in the soleus between the two groups was performed with a Pearson Chi-square test. A two-tailed probability value of less than 0.05 was considered statistically significant. Data are presented as means $( \pm \mathrm{SD})$, unless otherwise specified.

\section{RESULTS}

\section{Emphysema and Pulmonary Inflammation}

Airspace enlargement, reflected by a significantly higher Lm, was noted in the smoking mice as compared with the control group, as shown in Figure 1. In addition, in the BAL fluid, a marked increase of total inflammatory cells was observed after smoke exposure due to an accumulation of macrophages, neutrophils, and lymphocytes (Figure 2). 

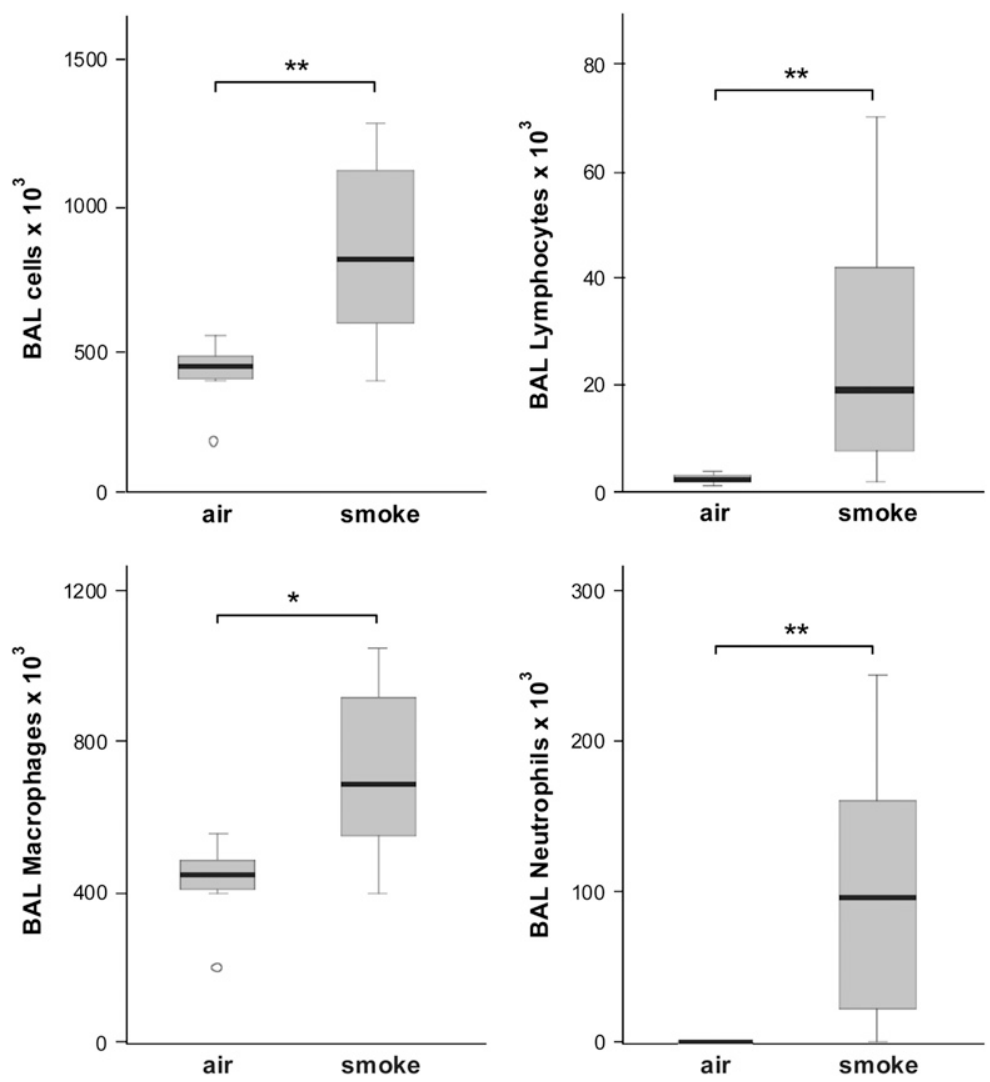

Figure 2. Box plots showing total cell number and numbers of differentiated cells (neutrophils, macrophages, and lymphocytes) in bronchoalveolar lavage (BAL) fluid. ${ }^{*} P \leqslant 0.05 ;{ }^{* *} P \leqslant$ 0.01. Black bars represent medians.

\section{Systemic Inflammation}

The most noteworthy findings for serum levels of chemokines and cytokines are shown in Figure 3. Serum TNF- $\alpha$ levels were significantly increased after chronic smoke exposure. The proinflammatory cytokines, IL-1 $\beta,-3$, and -17 , also tended to be increased in the smoke-exposed group. The proinflammatory chemokine, eotaxin, was also significantly increased after smoke exposure, with a similar trend for RANTES.

\section{Muscles: Weight, Fiber Type, and Metabolic Profile}

Weight parameters and tibia length are presented in Table 1. Body weight gain during the 24 weeks was attenuated in the smoke-exposed animals. This did not translate into statistically significant lower muscle weights, although the weight of the soleus tended to be lower in the smoking group $(P<0.06)$. Tibia length was the same for both groups.

MyHC content of hind-limb muscles after chronic exposure to air or cigarette smoke is presented in Figure 4. There was a small, though statistically significant, lower proportion of soleus muscle oxidative type-IIA fibers after smoke exposure,

TABLE 1. EFFECT OF 6 MONTHS OF CIGARETTE SMOKE EXPOSURE ON BODY WEIGHT, MUSCLE WEIGHT, AND TIBIA LENGTH

\begin{tabular}{lcc}
\hline Characteristics & Air-Exposed Mice & Smoke-Exposed Mice \\
\hline Body weight-gain, \% & $135.7 \pm 8.4$ & $126.7 \pm 4.8^{*}$ \\
Paired soleus weight, mg & $20.0 \pm 1.9$ & $18.7 \pm 1.4$ \\
Paired tibialis weight, mg & $98.6 \pm 7.0$ & $101.7 \pm 5.9$ \\
Paired gastrocnemius weight, mg & $299.3 \pm 18.2$ & $297.5 \pm 16.8$ \\
Paired plantaris weight, mg & $39.6 \pm 4.3$ & $38.0 \pm 3.3$ \\
Tibia length, mm & $23.6 \pm 0.5$ & $23.5 \pm 0.3$
\end{tabular}

\footnotetext{
"Paired" indicates that muscles from both hind limbs were weighed together. Data are presented as mean \pm SD.

$\star P<0.05$.
}

mainly concomitant with an increased proportion of glycolytic type-IIB fibers. Although not statistically significant, it is noteworthy that, in the soleus of the 13 mice exposed to air, only 4 showed a IIB band on the gel, whereas this was the case in 8 out of 13 mice exposed to cigarette smoke (Figure 4B).

The results of the muscle metabolic profile are shown in Figure 5. In all muscles examined in this study, the activities of all three oxidative enzymes (CtS, HAD, and cytochrome $c$ oxidase) tended to be lower after smoke exposure. However, a statistically significant difference between air- and smokeexposed mice was only found for $\mathrm{CtS}$ activity in the soleus $(342 \pm 47 \mathrm{U} / \mathrm{mg}$ protein versus $300 \pm 54 \mathrm{U} / \mathrm{mg}$ protein; $P=$ $0.050)$ and the tibialis anterior $(278 \pm 90 \mathrm{U} / \mathrm{mg}$ protein versus $218 \pm 32 \mathrm{U} / \mathrm{mg}$ protein; $P=0.042$ ). PFK was similar for both groups, although it tended to be higher in all muscles of the smoke-exposed mice.

\section{DISCUSSION}

The main observation of this study is that, in this in vivo animal model, chronic exposure to cigarette smoke results not only in emphysema and pulmonary inflammation, but also in increased circulating levels of mainly proinflammatory cytokines and chemokines. Furthermore, peripheral muscle metabolic profile shows a small but clearly present shift from oxidative toward glycolytic metabolism. Apart from a tendency toward reduced soleus weight after smoke exposure, muscle atrophy was not observed. Taken together, these systemic effects of smoking resemble what may represent the early onset of extrapulmonary manifestations in COPD.

\section{Smoke Exposure and Systemic Inflammation}

Systemic inflammation is a hallmark of COPD. The current data show that chronic exposure of $\mathrm{C} 57 \mathrm{Bl} / 6$ mice to cigarette smoke 

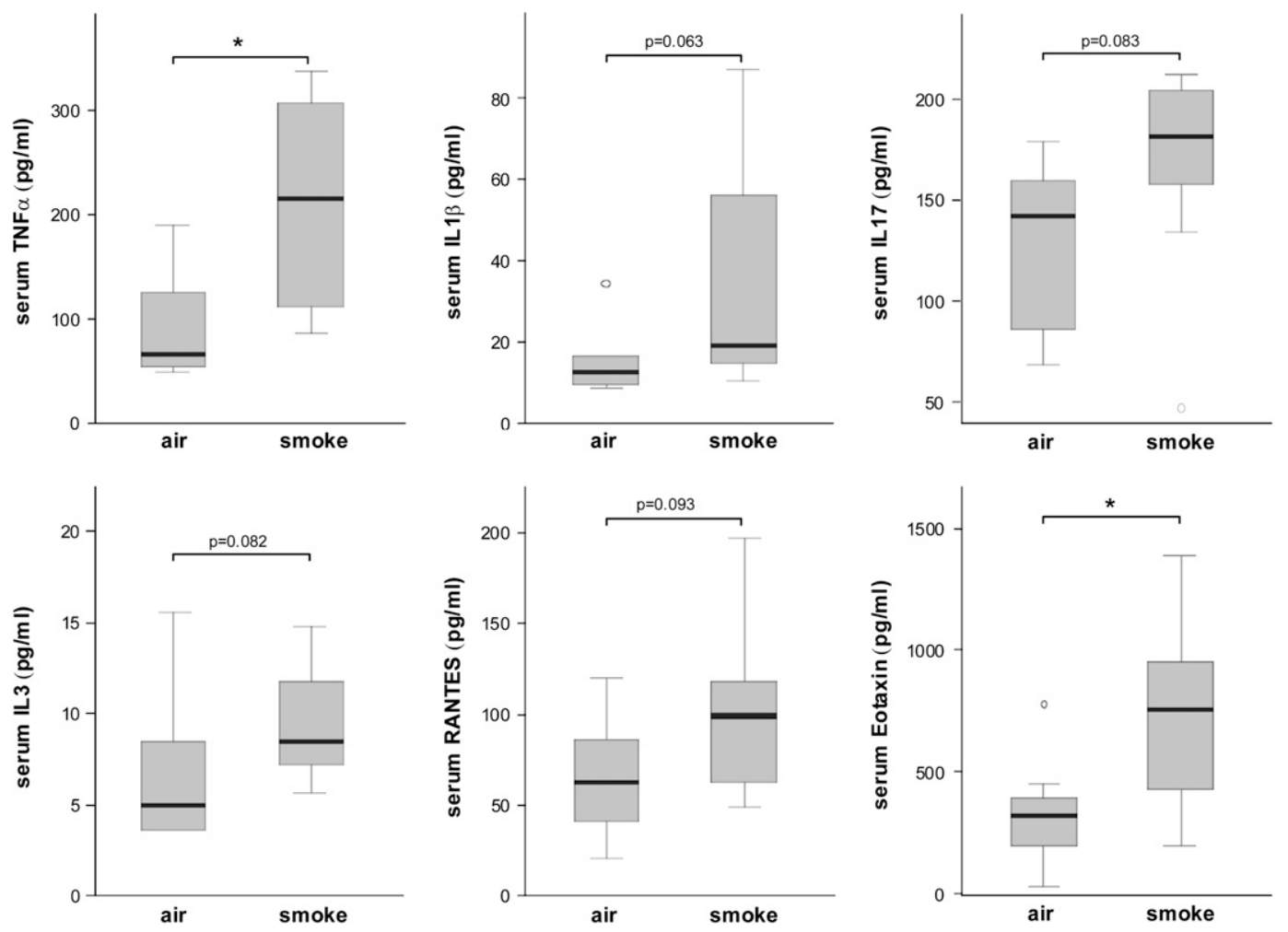

Figure 3. Box plots showing the serum levels of cytokines and chemokines. Black horizontal bars represent medians; open circles represent outliers (between 1.5 and 3 box lengths from the 75th or 25th percentile). There was one high extreme in all markers, except RANTES (regulated on activation, normal T-cell expressed and secreted), in the smokeexposed group, and box plots were generated after exclusion of those extremes ( $>3$ box lengths from the 75th or 25th percentile). ${ }^{*} P \leqslant 0.05$.

leads to a marked increase in circulating TNF- $\alpha$ and eotaxin levels and, to a lesser extent, of proinflammatory markers, IL$1 \beta,-3,-17$, and RANTES, representing systemic inflammation. Previously, another animal study showed a trend toward increased plasma TNF- $\alpha$ levels in guinea pigs after 6-month smoke exposure, which is consistent with the current data (22). Numerous human studies have shown that cigarette smoking is associated with systemic inflammation, as reviewed by our group recently (3). This includes increased levels and/or activation of circulating inflammatory cells, as well as proinflammatory cytokines. In most of these studies, pulmonary function was not assessed, so it cannot be excluded that some of the subjects already had respiratory disease (and/or other diseases related to smoking) that might account for systemic inflammation. Indeed, in the current report, emphysema was present in the smoking animals. Altogether, cigarette smoke can

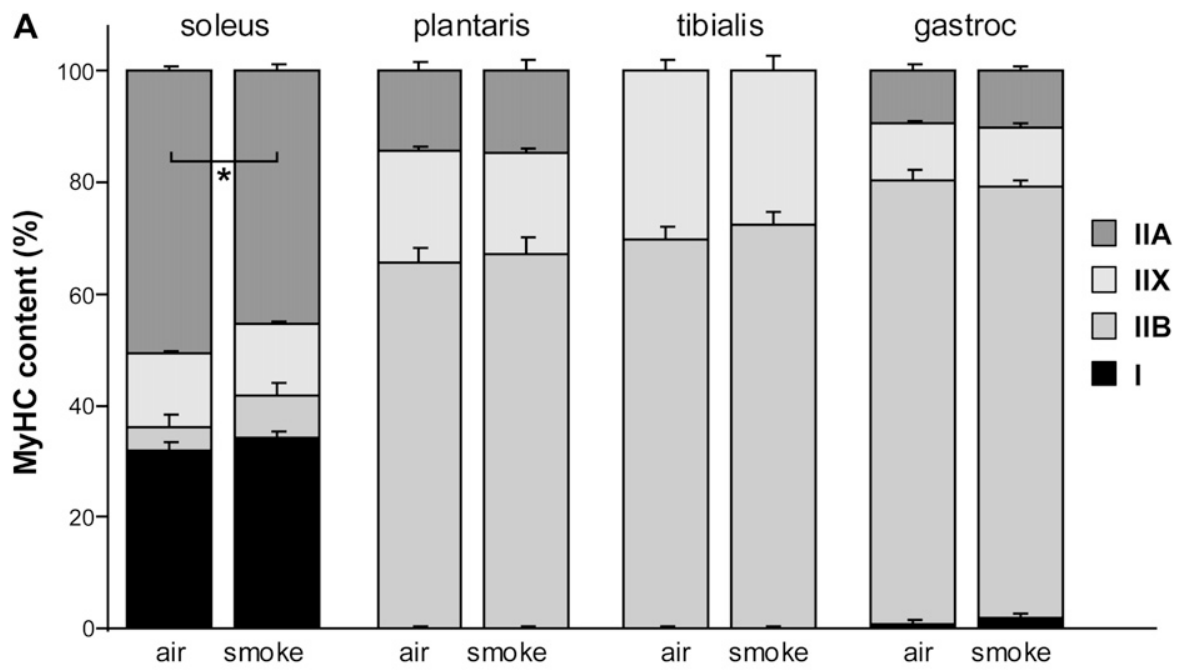

B

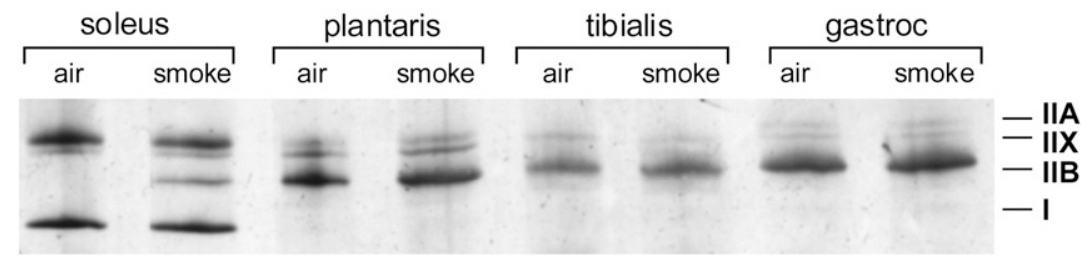

Figure 4. (A) Muscle myosin heavy-chain (MyHC) isoform content of hind limb muscles after chronic air or cigarette smoke exposure. ${ }^{*} P \leqslant 0.05$; error bars represent SEM. (B) Representative example of a silver-stained gel with $\mathrm{MyHC}$ isoform separation in the muscles examined. Note the absence of the IIB band in the soleus of the air-exposed animal, as opposed to its presence in the smoke-exposed animal. 

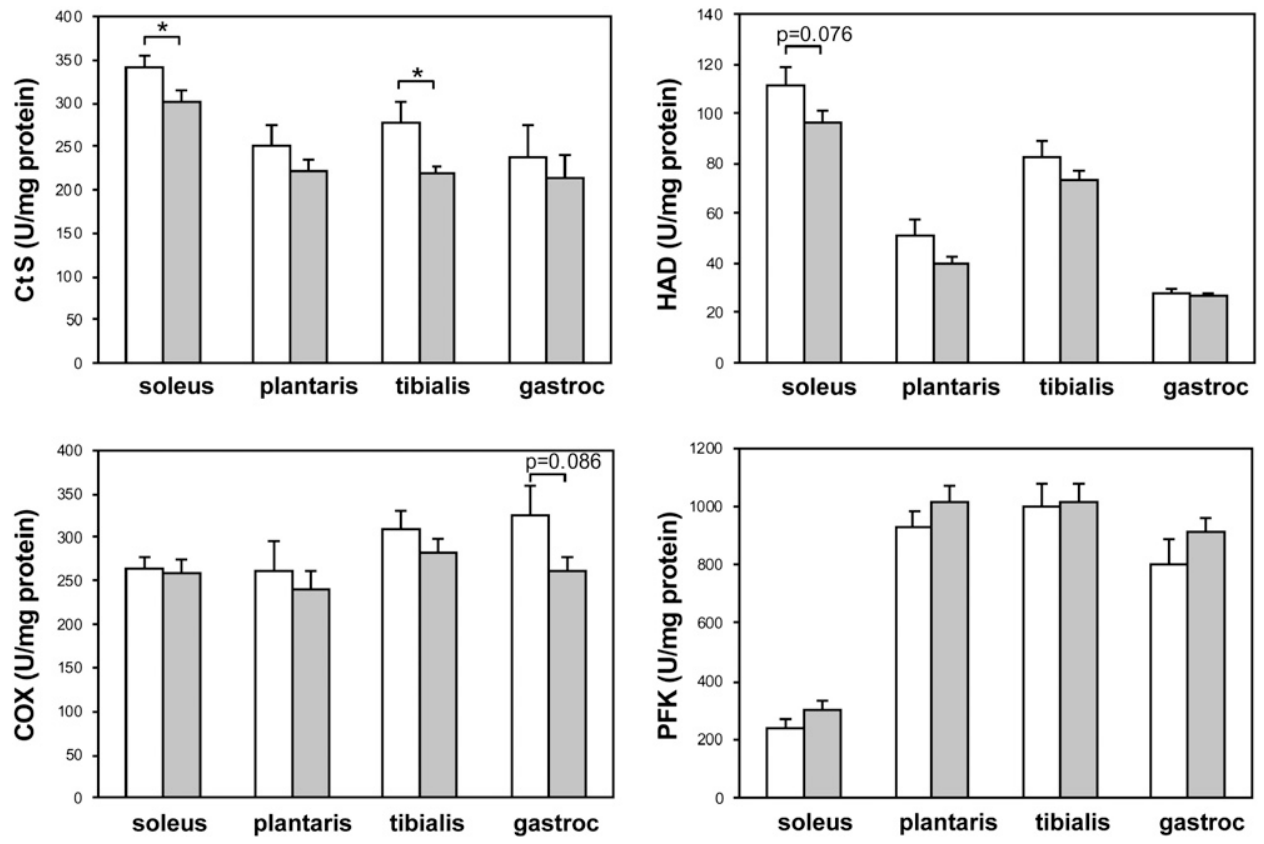

Figure 5. Muscle enzyme activities of hind-limb muscles after chronic air or cigarette smoke exposure. COX, cytochrome $c$ oxidase; $\mathrm{CtS}$, citrate synthase; gastroc, gastrocnemius; GlyP, glycogen phosphorylase; HAD, 3-hydroxyacyl-CoA dehydrogenase; PFK, phosphofructokinase. Open bars, air-exposed mice; gray bars, smoke-exposed mice. ${ }^{*} P \leqslant 0.05$; error bars represent SEM.

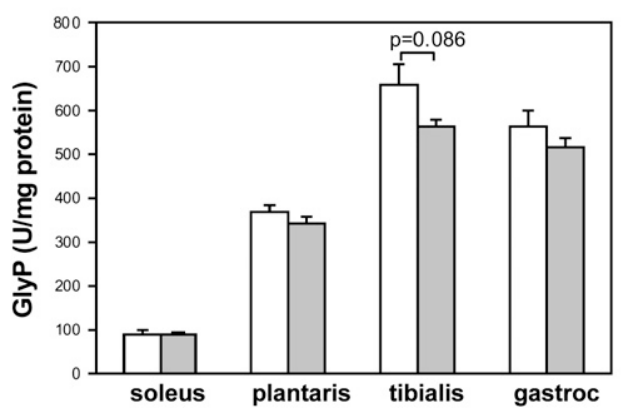

clearly lead to systemic inflammation, but whether this is a direct or indirect effect (secondary to pulmonary impairments) remains unclear.

\section{Smoke Exposure and Muscle Atrophy}

Evidence is accumulating that systemic inflammation is one of the major forces driving the loss of muscle mass in COPD and other chronic disorders. In addition, it has recently been shown that muscle protein turnover was shifted in favor of net protein breakdown in smoking as compared with nonsmoking individuals (23). However, literature is not consistent with respect to muscle atrophy in smokers: Orlander and colleagues (24) compared middle-aged smokers and nonsmokers, and found no muscle fiber atrophy in the smokers, whereas muscle atrophy was reported in smokers of smoking-discordant twin pairs (12). Presence of COPD and daily activity levels were not evaluated in these studies. All the same, no differences in quadriceps cross-sectional area were found between age, sex, and physical activity-matched non-COPD smokers and nonsmokers (25), whereas mild muscle fiber type-I and -IIA atrophy was recently found by Montes de Oca and colleagues (26) in non-COPD smokers versus healthy nonsmoking controls. Inconsistency also appears from the few animal studies that have been reported: Nakatani and coworkers (27) examined the effect of 2-month (thus, much shorter duration than in the current study) cigarette smoke exposure on the rat fast-twitch extensor digitorum longus, and in another report, the low-twitch soleus (28). At the highest dose, cigarette smoke induced a slight reduction in extensor digitorum longus weight and fiber cross-sectional area, but no effects of smoke exposure on these parameters were observed for the soleus. If any, atrophy in the current study seemed to be confined to the soleus muscle, a muscle that is mainly composed of highly oxidative type-I and -IIA fibers. The latter would be in line with the abovementioned study by Montes de Oca and colleagues (26). This would also imply that cigarette smoking is not the cause of the fiber type-IIX-specific atrophy observed in COPD (6). Overall, it remains unclear whether cigarette smoking leads to muscle atrophy, and, if so, whether it is fiber type-specific, and if it is not just a secondary effect to, for example, systemic inflammation. A possible explanation for the current absence of marked muscle weight loss might be that 6 months of smoke exposure were not sufficient, and that muscles were harvested in a phase in which atrophy was just starting to develop. Another explanation could be that potential muscle protein breakdown was sufficiently compensated by enhanced protein synthesis, which, unfortunately, was not assessed in the present study.

\section{Smoke Exposure and Muscle Metabolic Profile}

Loss of peripheral muscle oxidative phenotype in COPD is a consistent finding, and it is believed to be involved in augmented muscle fatigue in these patients. The current study shows that chronic cigarette exposure results in reduced activities of enzymes involved in oxidative metabolism, as well as a slight reduction of oxidative type-IIA fibers. Although a strong relationship exists between muscle oxidative phenotype (expressed as fiber 
type I proportion) and disease severity (i.e., primary lung impairment expressed as $\mathrm{FEV}_{1} \%$ predicted) (29), a direct effect of cigarette smoking cannot be ruled out. This is illustrated by studies in human subjects, in which a reduced muscle oxidative capacity was observed in smokers compared with nonsmokers $(12,24,26)$, reduced muscle oxidative capacity was observed in smokers compared with nonsmokers in all three studies. These findings clearly point toward a role of cigarette smoking in the loss of muscle oxidative phenotype.

\section{Mechanisms of Smoking-Induced Systemic Manifestations}

Whether muscle dysfunction in COPD is a direct effect of smoking or depends on emphysema and/or subsequent systemic inflammation remains to be determined. In the current study, no clear relationships between muscular changes, the degree of alveolar airspace enlargement, and parameters of systemic inflammation were found (data not shown). One way to resolve this question is to compare skeletal muscle size and oxidative phenotype in animal models in which systemic inflammation, emphysema, and cigarette smoke are uncoupled. For instance, whether emphysema is required for smoke-induced systemic inflammation and muscle alterations could be investigated in NZWlac/J mice, which do not develop emphysema in response to smoke exposure (30). Conversely, loss of muscle oxidative phenotype has been reported for emphysematous hamsters that had not been exposed to cigarette smoke (31), suggesting that emphysema is sufficient to induce muscle alterations. However, whether systemic inflammation is associated with these muscle alterations remains to be investigated in the hamster model. Skeletal muscle atrophy in presence of systemic inflammation and emphysema induced by chronic pulmonary inflammation has been shown in SP-C/TNF mice (32). Whether the musculature of these mice is also characterized by a reduced oxidative phenotype remains to be determined, as well as the requirement of the systemic inflammatory response on muscle alterations. Interestingly, the absence inflammatory signaling via TNF- $\alpha$ receptor 2 was shown to prevent emphysema (33) and affect smoke-induced skeletal muscle manifestations in TNF- $\alpha$ receptor 2 knock-out mice (34). Still, because systemic inflammation was not evaluated, it remains unclear whether the absence of emphysema or systemic inflammation affected the smokeinduced muscle abnormalities in these mice. Therefore, models of smoke exposure and emphysema in which systemic inflammation is modulated, as well as chronic systemic inflammation per se, will be required to determine the causal involvement of emphysema and systemic inflammation in smoke-induced muscle alterations.

\section{Study Limitations}

Approximately $20 \%$ of smokers develop COPD, suggestive of some genetic susceptibility. Likewise, the susceptibility for development of smoke-induced emphysema varies between mouse strains (30). Compared with the other strains, the C57Bl/6 mice showed moderate development of emphysema, but the largest difference in body weight after chronic smoke exposure. Because this systemic effect of smoking was most pronounced in $\mathrm{C} 57 \mathrm{Bl} / 6$ mice, this strain seemed the most appropriate for the present study. Nevertheless, it cannot be ruled out that more pronounced systemic differences would have been found if another mouse strain had been used. Similarly, only male animals were used, and other results might have been found in female mice. Another limitation of the current experimental design is that relatively young animals were used, which were still growing and gaining body weight. However, based on the similar tibia lengths, growth was not impaired by smoke exposure. The observed differences in body weight may, therefore, be confounded by attenuated weight gain instead of weight loss in the smoke-exposed animals, although this was apparently confined to reduced gain of fat mass and not of muscle mass. As discussed previously here, it is possible that, if the duration of the experiment-despite obvious practical concerns-was made even longer than the current 6 months, larger differences would have been found. Evidently, patients with COPD, for the most part, have a much longer smoking history (of many years), feasibly having lead to more pronounced systemic manifestations.

In summary, the present study shows that, in this in vivo animal model, long-term exposure to cigarette smoke not only leads to pulmonary inflammation and emphysema, but also the early signs of the extrapulmonary manifestations frequently observed in COPD, of which systemic inflammation and loss of oxidative phenotype in hind-limb muscles are most pronounced.

Conflict of Interest Statement: None of the authors has a financial relationship with a commercial entity that has an interest in the subject of this manuscript.

Acknowledgments: The authors thank Jodil Willems for laboratory assistance.

\section{References}

1. Rabe KF, Hurd S, Anzueto A, Barnes PJ, Buist SA, Calverley P, Fukuchi Y, Jenkins C, Rodriguez-Roisin R, van Weel C, et al. Global strategy for the diagnosis, management, and prevention of chronic obstructive pulmonary disease: GOLD executive summary. Am J Respir Crit Care Med 2007;176:532-555.

2. Fabbri LM, Pauwels RA, Hurd SS; GOLD Scientific Committee. Global strategy for the diagnosis, management, and prevention of chronic obstructive pulmonary disease: GOLD executive summary updated 2003. COPD 2004;1:105-141.

3. Yanbaeva DG, Dentener MA, Creutzberg EC, Wesseling G, Wouters EF. Systemic effects of smoking. Chest 2007;131:1557-1566.

4. ATS/ERS. Skeletal muscle dysfunction in chronic obstructive pulmonary disease: a statement of the American Thoracic Society and European Respiratory Society. Am J Respir Crit Care Med 1999;159: S1-S40.

5. Gan WQ, Man SF, Senthilselvan A, Sin DD. Association between chronic obstructive pulmonary disease and systemic inflammation: a systematic review and a meta-analysis. Thorax 2004;59:574-580.

6. Gosker HR, Engelen MPKJ, van Mameren H, van Dijk PJ, van der Vusse GJ, Wouters EFM, Schols AMWJ. Muscle fiber type IIX atrophy is involved in the loss of fat-free mass in chronic obstructive pulmonary disease. Am J Clin Nutr 2002;76:113-119.

7. Whittom F, Jobin J, Simard PM, Leblanc P, Simard C, Bernard S, Belleau R, Maltais F. Histochemical and morphological characteristics of the vastus lateralis muscle in patients with chronic obstructive pulmonary disease. Med Sci Sports Exerc 1998;30:1467-1474.

8. Jakobsson P, Jorfeldt L, Brundin A. Skeletal muscle metabolites and fibre types in patients with advanced chronic obstructive pulmonary disease (COPD), with and without chronic respiratory failure. Eur Respir J 1990;3:192-196.

9. Gosker HR, van Mameren H, van Dijk PJ, Engelen MPKJ, van der Vusse GJ, Wouters EFM, Schols AMWJ. Skeletal muscle fibre type shifting and metabolic profile in patients with COPD. Eur Respir J 2002;19:617-626.

10. Jakobsson P, Jorfeldt L, Henriksson J. Metabolic enzyme activity in the quadriceps femoris muscle in patients with severe chronic obstructive pulmonary disease. Am J Respir Crit Care Med 1995;151: 374-377.

11. Maltais F, Simard AA, Simard C, Jobin J, Desgagnes P, LeBlanc P. Oxidative capacity of the skeletal muscle and lactic acid kinetics during exercise in normal subjects and in patients with COPD. Am J Respir Crit Care Med 1996;153:288-293.

12. Larsson L, Orlander J. Skeletal muscle morphology, metabolism and function in smokers and non-smokers: a study on smoking-discordant monozygous twins. Acta Physiol Scand 1984;120:343-352.

13. D'Hulst AI, Vermaelen KY, Brusselle GG, Joos GF, Pauwels RA. Time course of cigarette smoke-induced pulmonary inflammation in mice. Eur Respir J 2005;26:204-213. 
14. Zeid NA, Muller HK. Tobacco smoke induced lung granulomas and tumors: association with pulmonary Langerhans cells. Pathology 1995; 27:247-254.

15. Bracke KR, D'Hulst AI, Maes T, Moerloose KB, Demedts IK, Lebecque S, Joos GF, Brusselle GG. Cigarette smoke-induced pulmonary inflammation and emphysema are attenuated in CCR6deficient mice. J Immunol 2006;177:4350-4359.

16. Ling KH, Pastkau V, Marcus F, Lardy HA. Phosphofructokinase. I. Skeletal muscle. Methods Enzymol 1966;9:425-429.

17. Bergmeyer HU, Gawehn K, Grassl M. 3-Hydroxyacyl-CoA dehydrogenase. In: Bergmeyer HU, editor. Methods of enzymatic analysis. Weinheim: Verlag Chemie GmbH; 1974. p. 474.

18. Shephard D, Garland PB. Citrate synthase from rat liver. Methods Enzymol 1969;13:11-16.

19. Gohil K, Jones D, Edwards R. Analysis of muscle mitochondrial function with techniques applicable to needle biopsy samples. Clin Physiol 1981;1:195-207.

20. Schreiber WE, Bowling S. An automated assay of glycogen phosphorylase in the direction of phosphorolysis. Ann Clin Biochem 1990;27:129-132.

21. Talmadge RJ, Roy RR. Electrophoretic separation of rat skeletal muscle myosin heavy-chain isoforms. J Appl Physiol 1993;75:2337-2340.

22. Ardite E, Peinado VI, Rabinovich RA, Fernandez-Checa JC, Roca J, Barbera JA. Systemic effects of cigarette smoke exposure in the guinea pig. Respir Med 2006;100:1186-1194.

23. Petersen AM, Magkos F, Atherton P, Selby A, Smith K, Rennie MJ, Pedersen BK, Mittendorfer B. Smoking impairs muscle protein synthesis and increases the expression of myostatin and MAFbx in muscle. Am J Physiol Endocrinol Metab 2007;293:E843-E848.

24. Orlander J, Kiessling KH, Larsson L. Skeletal muscle metabolism, morphology and function in sedentary smokers and nonsmokers. Acta Physiol Scand 1979;107:39-46.

25. Wust RC, Morse CI, de Haan A, Rittweger J, Jones DA, Degens H. Skeletal muscle properties and fatigue resistance in relation to smoking history. Eur J Appl Physiol 2008;104:103-110.
26. Montes de Oca M, Loeb E, Torres SH, De Sanctis J, Hernandez N, Talamo C. Peripheral muscle alterations in non-COPD smokers. Chest 2008;133:13-18.

27. Nakatani T, Nakashima T, Kita T, Ishihara A. Effects of exposure to cigarette smoke at different dose levels on extensor digitorum longus muscle fibres in Wistar-Kyoto and spontaneously hypertensive rats. Clin Exp Pharmacol Physiol 2003;30:671-677.

28. Nakatani T, Nakashima T, Kita T, Ishihara A. Responses of exposure to cigarette smoke at three dosage levels on soleus muscle fibers in Wistar-Kyoto and spontaneously hypertensive rats. Jpn J Pharmacol 2002;90:157-163.

29. Gosker HR, Zeegers MP, Wouters EF, Schols AM. Muscle fibre type shifting in the vastus lateralis of patients with COPD is associated with disease severity: a systematic review and meta-analysis. Thorax 2007;62:944-949.

30. Guerassimov A, Hoshino Y, Takubo Y, Turcotte A, Yamamoto M, Ghezzo H, Triantafillopoulos A, Whittaker K, Hoidal JR, Cosio MG. The development of emphysema in cigarette smoke-exposed mice is strain dependent. Am J Respir Crit Care Med 2004;170:974-980.

31. Mattson JP, Poole DC. Pulmonary emphysema decreases hamster skeletal muscle oxidative enzyme capacity. J Appl Physiol 1998;85: 210-214.

32. Langen RC, Schols AM, Kelders MC, van der Velden JL, Wouters EF, Janssen-Heininger YM. Muscle wasting and impaired muscle regeneration in a murine model of chronic pulmonary inflammation. Am J Respir Cell Mol Biol 2006;35:689-696.

33. D'Hulst AI, Bracke KR, Maes T, De Bleecker JL, Pauwels RA, Joos GF, Brusselle GG. Role of tumour necrosis factor-alpha receptor p75 in cigarette smoke-induced pulmonary inflammation and emphysema. Eur Respir J 2006;28:102-112.

34. De Paepe B, Brusselle GG, Maes T, Creus KK, D'Hose S, D’Haese N, Bracke KR, D'Hulst AI, Joos GF, De Bleecker JL. TNFalpha receptor genotype influences smoking-induced muscle-fibre-type shift and atrophy in mice. Acta Neuropathol 2008;115:675-681. 